\title{
Cara Penanganan yang Baik Pengolahan Produk Hasil Perikanan Berupa Udang
}

Rully Zulfikar

Program Studi Teknologi Pangan, Fakultas Peternakan dan Pertanian, Universitas Diponegoro, Semarang Korespondensi dengan penulis (ariel.rully@yahoo.co.id)

Artikel ini dikirim pada tanggal 3 Maret 2016 dan dinyatakan diterima tanggal 30 Maret 2016. Artikel ini juga dipublikasi secara online melalui www.jatp.ift.or.id. Hak cipta dilindungi undang-undang. Dilarang diperbanyak untuk tujuan komersial.

Diproduksi oleh Indonesian Food Technologists ${ }^{\circledR}$ (C2016

Negara Indonesia adalah negara maritim dengan didominasi wilayah lautan, sehingga dengan wilayah yang luas ini sangat memungkinkan untuk dimanfaatkan potensinya karena kandungan sumberdaya alam yang di dalamnya. Salah satunya adalah pantai yang panjang mendukung keanekaragaman dari sumberdaya alam yang terkandung didalamnya dan didukung tata letak dari negara Indonesia yang terdiri dari beribu-ribu pulau kecil dan besar yang ada didalamnya, dengan demikian maka negara Indonesia memiliki kekayaan perairan yang berupa ikan yang beraneka ragam macamnya, kerang-kerangan, rumput laut, hutan bakau, crustacean, decapoda, cumicumi, udang dan masih banyak lagi biota yang terkandung didalamnya

Ikan merupakan salah satu bahan makanan yang mudah membusuk. Hal ini dapat dilihat pada ikan yang baru ditangkap dalam beberapa jam saja kalau tidak diberi perlakuan atau penanganan yang tepat. Penanganan ikan basah harus dimulai segera setelah ikan diangkat dari air tempat hidupnya, dengan perlakuan suhu renda dan memeperhatikan faktor kebersihan dan kesehatan. Salah satu hasil perikanan yang terbesar di indonesia adalah udang. Udang merupakan bahan makanan yang bernilai tinggi dan digemari oleh banyak orang, baik di dalam negeri maupun di luar negeri. Penilaian tersebut didasarkan atas nilai komersial dan nilai gizinya. Banyak permintaan produk berupa udang segar baik di indonesia maupun diluar negeri maka dari itu harus cara penanganannya harus diperhatikan supaya udang tidak rusak maupun busuk pada saat di kirim, maka dari itu salah satu penanganannya dengan cara pembekuan.

Prinsip dasar dari pembekuan adalah suatu cara pengawetan bahan pangan dengan cara membekukan bahan pada suhu titik beku pangan tersebut. Seiring dengan membekunya sebagian kandungan air bahan atau dengan terbentuknya es maka ketersediaan air menurun, akibatnya kegiatan enzim dan jasad renik dapat dihambat atau dihentikan yang pada akhirnya dapat mempertahankan mutu bahan pangan. Pembekuan dapat mempertahankan rasa dan nilai gizi bahan pangan yang lebih baik daripada metode lain, karena pengawetan dengan suhu rendah yaitu pembekuan dapat menghambat aktivitas mikroba, mencegah terjadinya reaksi-reaksi kimia dan aktivitas enzim yang dapat merusak kandungan gizi bahan pangan. Proses produksi penanganan udang beku yang baik pada salah satu perusahaan pengolahan ikan yaitu yang harus dilakukan adalah mulai dari penerimaan bahan baku, sortasi, perendaman, penimbangan, pencucian, penyusunan, pembekuan, glazing, pengemasan dan pelabelan, cold strage, eksport. Penerimaan bahan baku merupakan proses penerimaan bahan baku dari berbagai daerah atau suplier. Proses penerimaan bahan baku (receiving) merupakan tahap awal dari semua proses dalam pengolahan, dimana bahan baku yang telah diterima dari supplier baik udang hasil budidaya maupun udang tangkapan lainnya yang langsung dibawa ke perusahaan untuk diolah menjadi produk sesuai permintaan buyer. Udang segar diluar pabrik berada dalam bak Fiberglass atau blogblog plastic yang diberi es kemudian segera dibongkar di ruang penerimaan. Penerimaan bahan baku ini harus dicontrol oleh yang ahli dalam bidang nya yaitu QC.

Sortasi yaitu untuk mengelompokkan udang berdasarkan range size yang dibutuhkan atau diinginkan. Sortasi dilakukan dengan tenaga manusia yang meliputi sortasi mutu, ukuran dan warna. hasil sortasi ditampung pada keranjang dan selanjutnya akan ditaruh pada meja-meja karyawan yang berbahan stainless steel yang berjumlah 8 buah untuk dilakukan pemisahan berdasarkan mutu, ukuran dan warna. Proses selanjutnya adalah perendaman yang bertujuan untuk mengembalikan berat udang setelah melalui beberapa proses sebelumnya. Larutan yang digunakan untuk soaking adalah STPP posphat yang berfungsi sebagai food aditif yang bertujuan untuk meningkatkan kekenyalan produk, brisol, garam dan air bersuhu 0-3 $\mathrm{C}$ proses perendaman ini dilakukan di fiber yang berisi air es selama 30 menit -1 jam.

Penimbangan merupakan penimbangan yang dilakukan untuk mengetahui berat, size dan banyaknya udang dalam satu wadah yang berisi produk udang beku. Tujuan penimbangan yaitu, untuk mengetahui berapa banyak udang yang akan jadi produk udang beku yang siap dibekukkan, dalam proses penimbangan ini rantai dingin tetap diperhatikan pada tiap meja penimbangan dilapisi dengan es curai agar udang yang menunggu untuk ditimbang tetap terjaga mutunya, suhu yang digunakan yaitu $2^{\circ} \mathrm{C}$. Kemudian setelah proses penimbangan dilakukan pencucian dengan air yang dicampur dengan es dan chlorine 2535 ppm. Pencucian dengan cara disiram 1 kali setelah itu raw material dicelup kedalam air chlorine yang kapasitasnya 25-35 ppm dan celup kembali raw material kedalam air biasa, supaya udang yang banyak mengandung chlorine dapat tercuci,standar suhu air pencucian yaitu $0-3^{\circ} \mathrm{C}$. 
Udang yang telah ditimbang kemudian disusun di ruang penyusunan, udang disusun didalam inner pan oleh karyawan/pegawai di bagian penyusunan, penyusunan dilakukan berdasarkan hasil penimbangan agar ukuran udang dalam satu inner pan seragam. Penyusunan dilakukan dengan hati - hati agar tekstur udang tidak rusak. Tahap penyusunan udang dalam pan harus sesuai dengan aturan. Peraturan ini tergantung dari size udang. Udang yang telah disusun ke dalam pan kemudian diberi air es suhu $<5^{\circ} \mathrm{C}$ sampai penuh, kemudian ditutup dengan penutup pan yang dilapisi plastik blok. Pemberian air es ini bertujuan untuk mencegah terjadinya dehidrasi dan perubahan warna pada udang, jika udang telah disusun diatas plate kemudian CPF ditutup dengan rapat. Lama pembekuan pada CPF yaitu 4 jam dengan suhu $-40^{\circ} \mathrm{C}$. Udang yang telah dibekukkan selama 4 jam lalu kemudian di proses selanjutnya yaitu proses glazing yaitu untuk mencegah terjadinya oksidasi, dehidrasi dan memperbaiki penampilan karena terbentuk lapisan es tipis yang seragam, Glazing dilakukan dengan cara mencelupkan udang blok ke dalam bak yang berisi air dingin yang berjumlah 1 buah dan semprotan air dari pipa paralon yang diberi lubang.

Proses selanjutnya setelah di glazing adalah pengemasan dan pelabelan sebelum produk ini di masukkan dalam cold stroge. Cara pengemasan dan pelabelan ini yaitu dengan terlebih dahulu produk dimasukkan kedalam plastic block yang berwarna bening kemudian dilakukan penggecekan inner carton dengan melihat kode expire, data dan size. Pengemasan ini bertujuan untuk melindungi produk dari resiko kerusakan cacat fisik, mempermudah identifikasi produk, mempermudah distribusi dan juga memperindah penampilan dari pada produk. Pengemasan dan pelabelan selesai dilakukan kemudian produk dimasukkan kedalam cold stroge merupakan penyimpanan terakhir dari produk sebelum diekspor, dimana produk disimpan dengan menyusun berdasarkan sizenya, hal ini dilakukan agar saat akan dilakukan pengiriman barang petugas yang bertugas tidak akan kesulitan untuk mencari produk yang dimaksud. Selain itu cara penyusunan disini harus diperhatikan karena apabila cara penyusunan tidak sesuai standar maka akan berakibat pada produk yang dibekukan karena dapat merusak kemasan bahkan produk didalamnya tertindih oleh produk lainnya. Tujuan dari penyimpanan udang dalam cold storage yaitu untuk menjaga kondisi udang beku agar selama menunggu proses pemasaran tetap dalam kondisi yang segar dan masih fresh. Ekspor merupakan kegiatan dimana produk yang telah diolah dan selesai dipacking kemudian siap untuk dipasarkan atau di ekspor ke negara tujuan. Suhu dari container yang akan membawa produk tersebut harus memiliki standar suhu yaitu $-18^{\circ} \mathrm{C}$, karena produk sampai ke tangan buyer harus dalam keadaan segar sesuai dengan standar permintaan buyer.

Cara penanganan yang baik dan tepat akan menghasilkan produk yang berkualitas tinggi dan tidak mudah rusak dan aman untuk dikonsumsi. Penjelasan diatas adalah salah satu cara penanganan yang baik untuk produk udang yang dibekukkan dan tidak mudah rusak udang dalam perjalanan pada saat dikirim ke konsumen.

\section{Daftar Pustaka}

Adawyah, R. 2007. Pengolahan dan Pengawetan Ikan. Bumi Aksara : Jakarta.

Afrianto , E dan Liviawati E. 2003. Pengawetan dan Pengolahan Ikan. Kanisius: Yogyakarta.

Afrianto , E Liviawati E. 2010. Penanganan Ikan Segar. Widya Padjajaran. Bandung.

Arfiati , D. 2006. Diktat Kuliah Ictyollogi. Fakultas Perikanan dan IImu Kelautan. Universitas Brawijaya. Malang 